\title{
The Milestones of the Persian Gulf Security Developments
}

\author{
Seyed Mohsen Mirhosseini*, Elham Rasoulisaniabadi \\ Department of Political Science, Faculty of Human Science, Yazd University, Iran
}

Copyright $@ 2015$ Horizon Research Publishing All rights reserved.

\begin{abstract}
Security of the Persian Gulf region has been confronted many challenges during the history because of the geopolitical and geo-economical role of this region for western countries and superpowers especially after the occurrence of the Islamic Revolution in Iran in 1979. Objective of this paper is to discus and evaluate the challenges of the regional security arrangements by the US in the Persian Gulf. In this regard, Buzan's theory (Regional security complexes) is applied to undertake the reasons of insecurity in this region. Data are collected from articles, books and journals based on qualitative method. The main finding of the paper expresses that according on buzan's theory rivalries of local states in the region has caused the penetration of the external powers such as United States.
\end{abstract}

Keywords Persian Gulf, Regional Security, the United States, Iran

\section{Introduction}

Since the withdrawal of United Kingdom forces from east of Suez and the Persian Gulf region in 1971, the security system of this region has been confronted with many challenges and the concerns about security have been reintroduced into the debate on the world order and enhanced the previous efforts of the United States of America to establish a balance of power security system against the Soviet Union. Furthermore, the end of formal domination of the United Kingdom since 1971 brought to the debate the issue of security studies and related questions in the Persian Gulf region.

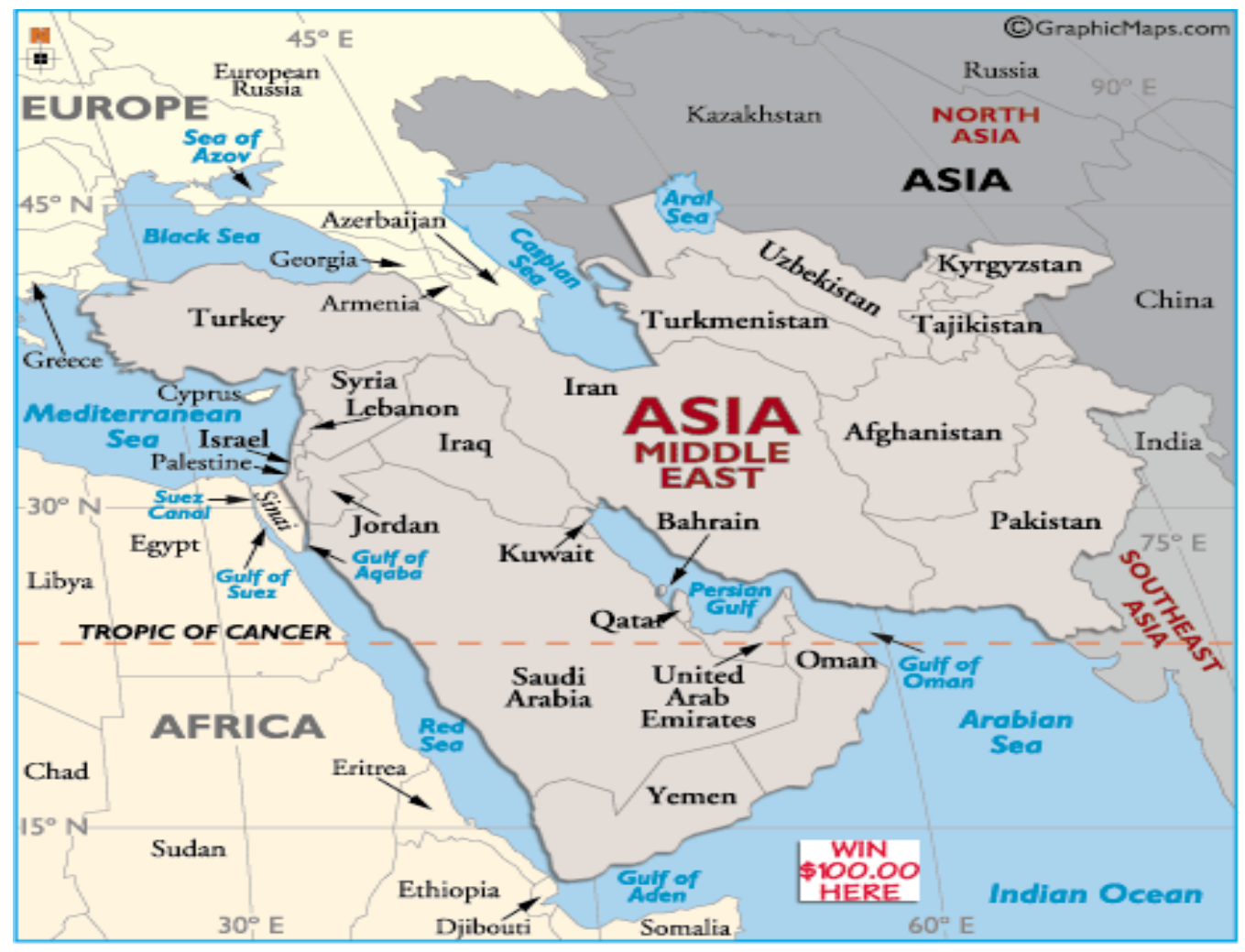

Source: indymedia.org.uk (2012)

Figure 1. The Middle East \& Persian Gulf region 


\section{Background of the Study}

Regional security and the interdependence of security have always been at the core of security studies by scholars in this field. In security systems studies, states are the basic units in the international system and their autonomy is affected by the regional sub-systems. In the state-centric view, the basic assumption is that states are the primary actors in the international system and are also the legitimate providers of security. In a region like the Persian Gulf, regional states of the Persian Gulf area (Iran, Iraq, Saudi Arabia, United Arab Emirates, Kuwait, Qatar, Bahrain, Oman), have a vital role in security policies of the region.

On the other hand, super powers and external powers in important regions of the world including Persian Gulf region have their benefits and interests. In this regard, they want to create a balance of power in favor of themselves and in this process, they attempt to maintain or change the security systems of such regions. Logic of balance of power is penetration of external powers in these regions and penetration is caused by indigenous regional rivalry among local states in the regions. So securization and desecurization of each state in the region is in interaction with other states of the region and finally this interaction leads to national security of all regional states.

The background of the this study will be discussed in three parts: the importance of the Persian Gulf geopolitics, US past attempts for building security system in the Persian Gulf region and today's feature of the Persian Gulf region.

\subsection{The Importance of the Persian Gulf Geopolitics}

The Persian Gulf region has its importance in its particular geo-economic, geostrategic and geopolitical situation. In this regard, the Persian Gulf region has been the focus of regional and extra-regional powers throughout the course of history. Economically, almost two thirds of the proven oil reserves in the world (65percent) and more than one third of the global natural gas reserves (40percent) are located in the Persian Gulf region. Moreover, 20percent of the world's oil trade is done through this region. According to the latest statistics, almost 23 million barrels of oil (nearly 27 percent of global production) are produced daily by the Persian Gulf states. Also, according to the International Energy Agency's estimate, in 2025, the Persian Gulf states will be exportingdaily36.4 million barrels of crude oil [1].On the other hand, two other advantages of the fossil energies of the Persian Gulf distinguish the region from others: 1) lower costs of exploitation of crude oil and natural organs in comparison with other regions; 2) the crude oil reserves are located close to efficient and developed transport routes with access to various markets [1]. Geopolitically, the Persian Gulf is located in the area where Europe, Africa and Asia meet. This means that it is directly affected by events in those continents. From the geo-strategic perspective the Persian Gulf has been a military pathway to access other regions that is among the factors making the region important to major powers of the world.

The major indexes and geopolitical feature of the region is its highest volume of fossil fuel exports to the world. Proven crude oil reserves of the Persian Gulf coastal states of Iran, Iraq, Saudi Arabia, Kuwait, Qatar, the United Arab Emirates, Oman and Bahrain stand at around 65percent of the world's total oil reserves and 28percent of the global oil supplies. Saudi Arabia has nearly 25 percent of the world's crude oil reserves, followed by Iran, Iraq, Kuwait and the UAE. Therefore, the four Persian Gulf coastal states of Saudi Arabia, Iran, Iraq and Kuwait, jointly possess over 55 percent of proven global oil reserves. So Persian Gulf is the most well-known energy pole of the world [2].

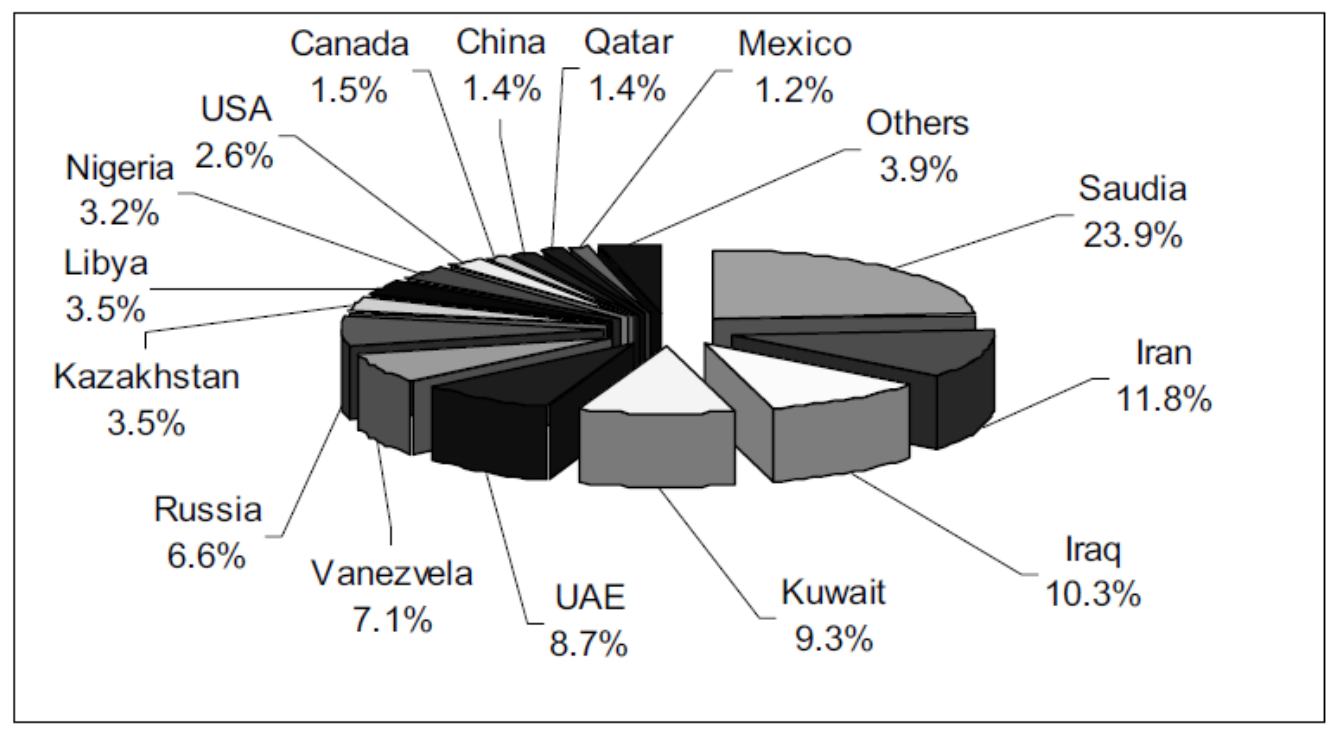

Figure 2. Distribution of global Oil Reserves. (EIA, 2009) 
The Persian Gulf coastal states (Iran, the United Arab Emirates, Bahrain, Iraq, Saudi Arabia, Oman, Kuwait, Qatar and Yemen) also score high in terms of crude oil production. In 2002, they produced 27percent of the world's total production. The region's natural gas reserves stand at around 45 percent of world's total gas reserves. According to energy international agency (2006), approximately 80percent of all proven natural gas reserves of the Middle East lie in the Persian Gulf. The area produces around 32percent of world's total crude production [3]. The dependence of The Organization for Economic Co-operation and Development (OECD) states on Persian Gulf oil is much more than the United States. Whereas the United States imports 45 percent of its oil, 25percentof which comes from the Persian Gulf, OECD imports 57percent of its oil from the Persian Gulf and Japan 70percent. In this context, while the OECD annually spends USD \$200 billion on Persian Gulf oil, the United States alone accounts for half that sum[4].

Table 1. World Conventional Oil Production

\begin{tabular}{cccc}
\hline \multicolumn{4}{c}{$\begin{array}{c}\text { World Conventional Oil Production } \\
\text { Average 000/b/d }\end{array}$} \\
\hline Year & World & OPEC & $\begin{array}{c}\text { OPEC \% } \\
\text { World }\end{array}$ \\
\hline 2005 & 73,737 & 32,938 & 45 \\
2006 & 73,461 & 36,610 & 44 \\
2007 & 73,015 & 32,174 & 44 \\
2008 & 73,791 & 33,441 & 45 \\
\hline
\end{tabular}

(Source: Energy International Agency, 2009, p: 38)

*Organization of petroleum exporting countries (OPEC)

On the other hand, political risk is exacerbated by choke points in transit routes. Nearly 40percent of world oil exports pass through the Strait of Hormuz, nearly 28percent through the Strait of Malacca, and nearly 7percent through Bab-al-Mandeb, the narrow strait connecting the Red Sea and the Gulf of Aden [5]. Because of the importance of crude oil in the industrialized world, foreign direct investment (FDI) in the Middle East and especially the Persian Gulf region, expanded by more than 200percent between 2001 and 2006 and also multinationals raced to gain a foothold in this fast-growing region [6]. At the same time, Gulf states' foreign assets have more than doubled since 2003, with estimates ranging from USD $\$ 1.8$ trillion to USD $\$ 2.4$ trillion [7].

Richard Sokolsky, an adjunct research associate at the National Defense University's Institute for National Strategic Studies in Washington, D.C. believes that the Persian Gulf also will remain the main source of Western energy supplies over the 2010 decade and the portion of Western Europe's total oil consumption imported from the Persian Gulf will increase to 35percent, compared to 14percent for the United States. According to the 2006 International Energy Outlook Report, the volume of US energy imports from 29percent in 2004 will increase to 32-33percent of its energy demands in 2030 [8] and Persian Gulf is the main source of US oil imports. Also, according to a 2008 International Energy Agency report, staying on the present path would bring about a 70percent increase in oil demand by 2050 [9]. Henry Kissinger, after the 1973 oil price shock, argued that U.S. security had been directly affected by the imported energy:

In the last three decades, we have become so increasingly dependent on imported energy that today our economy and well-being is hostage to decisions made by nations thousands of miles away [.... The energy crisis has placed at risk all of this nation's objectives in the world. It has mortgaged our economy and made our foreign policy vulnerable to unprecedented pressures [10].

The Persian Gulf is also an effective geo-strategic center in the international system. Its role in generating religious and political thoughts; Iran's geographical position between Russia and the newly-established republics and their link to the Persian Gulf, the Sea of Oman and the Indian Ocean; Saudi Arabia's access to the strategic waterways of the Sea of Oman, the Persian Gulf, the Red Sea, the Indian Ocean; stretching to the Suez Canal and the European continent through the Strait of Babol-Mandab [11]. In this regard, Captain Alfred Thayer Mahan, US naval officer and author of key works on naval strategy in 1902 expressed the belief that Britain should take up the responsibility of maintaining security in the (Persian) Gulf and its coasts - the 'Middle East' - so that the route to India would be secured and Russia kept in check [12].

\section{U.S. Past attempts to Build a Security System for the Persian Gulf}

The security of the Persian Gulf, especially since the discovery of oil resources in this region, has always been a critical issue among the regional member states, the international community and the industrial world. Before the Islamic Revolution in Iran in 1979, the Arab Persian Gulf states had an unimportant role in the security of the Persian Gulf region. Just before 1971, Britain saw itself as responsible for ensuring the region's security, its vast oil reserves and the flow of free trade until World War II [11].

The US sought to establish a new security system to fill the power vacuum in the region after Britain's disengagement from east of Suez (and also the Persian Gulf area) in 1971. The US policy was based on the firm belief that Western (indeed global) prosperity is tied to the security of oil supplies from the Persian Gulf. Given the hard lessons learned in Vietnam, Washington did not want to send its troops to the Persian Gulf. Instead, the Nixon Administration formulated the 'twin-pillar' policy: reliance on two regional powers (Iran and Saudi Arabia) to protect oil resources from any hostile threat. Of the two, Iran was regarded as being militarily more capable of securing western interests and politically more stable than Saudi Arabia. The Iran's Shah was thus given almost unlimited access to the most sophisticated US weaponry and gradually came to be regarded as the "Policeman of the Persian Gulf" according to 
"twin pillar policy" of Nixon administration [13].

Two important developments led to the collapse of the "twin-pillar policy" at the end of 1979. First, the Pahlavi regime in Iran was overthrown and replaced by the Islamic Republic and the leadership of the Ayatollah Khomeini. Second, Soviet troops invaded Afghanistan and were in a position to pose a direct threat to oil supplies from the Persian Gulf. These two developments caused hard changes in U.S policy in the region, promulgated in the "Carter Doctrine'. According to this new policy: "any attempt by outside forces to gain control of the Persian Gulf region would be regarded as an assault on the vital interests of the U.S.A and as such would be repelled by any means necessary, including military force" [14]. Thus, Washington shifted from relying on regional powers to a readiness to use its own military force to defend oil resources. In line with this new strategy, Carter authorized the creation of the Rapid Deployment Joint Task Force. (Later renamed the U.S. Central Command [USCENTCOM])

During 1993-1997, the Clinton Administration expressed the policy of "dual containment," According to this policy; US effort was to keep Iran and Iraq weak rather than alternately tilting toward one or the other to preserve a power balance between them. On the other hand, during the Clinton dual containment policy, the Kingdom of Saudi Arabia and Sheikhdom of Kuwait were primarily concerned about the conventional threat from Iraq and saw Iran as a counterweight to Iraqi power. The dual containment policy also had little success in curbing Iran's and Iraq's activities [15].

\section{Feature of the Region after U.S. Attack of Iraq}

Ever since Britain's announcement that it planned to withdraw from east of the Suez Canal in 1971, there have been repeated efforts to find an effective Persian Gulf security system. There are five characteristics of the Persian Gulf strategic environment that have the greatest impact on future U.S. strategy in the Persian Gulf region: a global dependence on regional oil exports; the rising threat posed by violent sub-state forces; the proliferation of weapons of mass destruction; uncertain political, economic, and social reform trends; and the future stability of Iraq.

The facts show the failure of attempts by regional and outside actors alike to develop a functional security system; because today's system depends on the readiness of the United States to increase dangerous wars and to maintain a military presence despite local countries with weapons of mass destruction in the region. With Persian Gulf oil supplies as vital as ever to the global economy, the quest for reliable security has never been more important. Yet, even during conflicts and wars in the Persian gulf region, there has been little public debate in the region, Europe, or the United States, and little genuine analysis, on the shape of a post-war system to help break the cycle of instability and conflict that has plagued the region. Although opponents of war argue that it is destabilizing the region, they have no practical ideas on how to improve or replace the current security arrangement, which has lurched from crisis to crisis.

The time is ripe for scholars to offer ideas that can help stabilize the region. The nations of the Middle East and especially the Persian Gulf have suffered greatly from military conflict over the past four decades, including the ongoing conflict in Iraq, the 1991 war in Kuwait, and the 1980-88 Iran-Iraq war. The existing Persian Gulf security system, without participation of all states, only offers the chance to stabilize the region for the short to medium term and is not compatible for a long time. For the time being, the formation of a Persian Gulf wide cooperative security forum would increase regional security and give recognition to all legitimate security concerns and could play an increasingly important role as the forum matures [16].

There are more subtle developments that permit a new and better security system to be built after Saddam's removal from power in 2003. One is the growing acceptance by elites in Saudi Arabia and the smaller Persian Gulf Cooperation Council (GCC) states of the need for domestic reform. The other development, obscured by rhetoric on both sides, is the growing possibility that America believes any arrangements without the presence of all states in the Persian Gulf region cannot be stable as has been shown and Iran can be certain that the U.S has its interests in the Persian Gulf.

\section{Buzan's Theory and Security in the Persian Gulf}

When we compare the stability of the Persian Gulf with the "Regional security complex theory" there appears a meaningful relationship between stability of the Persian Gulf and rivals of the local states in the region.

According to the theory (Barry Buzan) the original definition of a security complex was: 'a group of states whose primary security concerns link together sufficiently closely that their national securities cannot reasonably be considered apart from one another' (Buzan, 1983a, p. 106). Buzan and Waver in 1998 in their book reformulated the above definition of RSCs to shed the state-centric and military-political focus and to rephrase the same basic conception for the possibility of different actors and several sectors of security: 'a set of units whose major processes of securitization, desecuritisation, or both are so interlinked that their security problems cannot reasonably be analyzed or resolved apart from one another'. [17]

One of the purposes of RSCT is to combat the tendency to overstress the role of the great powers, and to ensure that the local factors are given their proper weight in security analysis. The standard form for an RSC is a pattern of rivalry, balance-of power, and alliance patterns among the main powers within the region: to this pattern can then be added the effects of penetrating external powers. Normally the pattern of conflict stems from factors indigenous to the 
region - such as, in the Middle East - and outside powers cannot usually define, desecurity, or reorganize the region. [17]

"Regional security complex" is not just a perspective that can be applied to any group of countries. In order to qualify as an RSC, a group of states or other entities must possess a degree of security interdependence sufficient both to establish them as a linked set and to differentiate them from surrounding security regions.

The theory specifies what to look for at four levels of analysis:

1. Domestically in the states of the region, particularly their domestically generated vulnerabilities (is the state strong or weak due to stability of the domestic order and correspondence between state and nation)

2. state-to-state relations (which generate the region as such);

3. The region's interaction with neighboring regions.

4. The role of global powers in the region (the interplay between the global and regional security structures) [17].

In sum, The theory offers the possibility of systematically linking the study of internal conditions, relations among units in the region, relations between regions, and the interplay of regional dynamics with globally acting powers. [17]

Buzan and waever then explain about Sub-complexes and believe that Sub complexes have essentially the same definition as RSCs, the difference being that a sub-complex is firmly embedded within a larger RSC. Sub-complexes represent distinctive patterns of security interdependence that are nonetheless caught up in a wider pattern that defines the RSC as a whole. The clearest example is in the Middle East, and in the Persian Gulf (Iran, Iraq and GCC). Sub-complexes are not a necessary feature of RSCs, but they are not uncommon either, especially where the number of states in an RSC is relatively large.

Buzan and Waever believe that the Persian Gulf sub-complex formed after Britain's withdrawal from the area in 1971. It centered on a triangular rivalry among Iran, Iraq, and the Persian Gulf Arab states led by Saudi Arabia.

Buzan and waever believe that the contemporary structure of international security, is almost the reverse of that set out in Huntington's widely read Clash of Civilizations (1993). They are Similar in emphasizing the importance of a distinct middle level between state and global system. Huntington emphasizes how large civilizations like Islam, the West, and Asia clash, and how the really dangerous conflicts emerge at the fault lines of these culturally based macro-units (Huntington, 1993).[18]

Buzan and waever stress that security regions form subsystems in which most of the security interaction is internal. At last they conclude that Huntington's delineation of the regions/civilizations differs at several points because his are seen as reflections of underlying cultural affinities, whereas RSCs are defined by the actual patterns of security practices.

According to the below chart; rivalries in the region will cause the penetration of the external powers such as United States. In this regard, for example territorial disputes between Iran and the UAE over three islands of Abu Musa and lesser and grater Tunbs in the Persian Gulf will lead to rivalry and disputes between the regional states and in consequence, regional collective security and a comprehensive regional security forum will not be formed. So; the states of the Persian Gulf region should recognize the existing security threats that are originated inside the region and between themselves to avoid any tensions that may cause rivalry and struggle between local states.

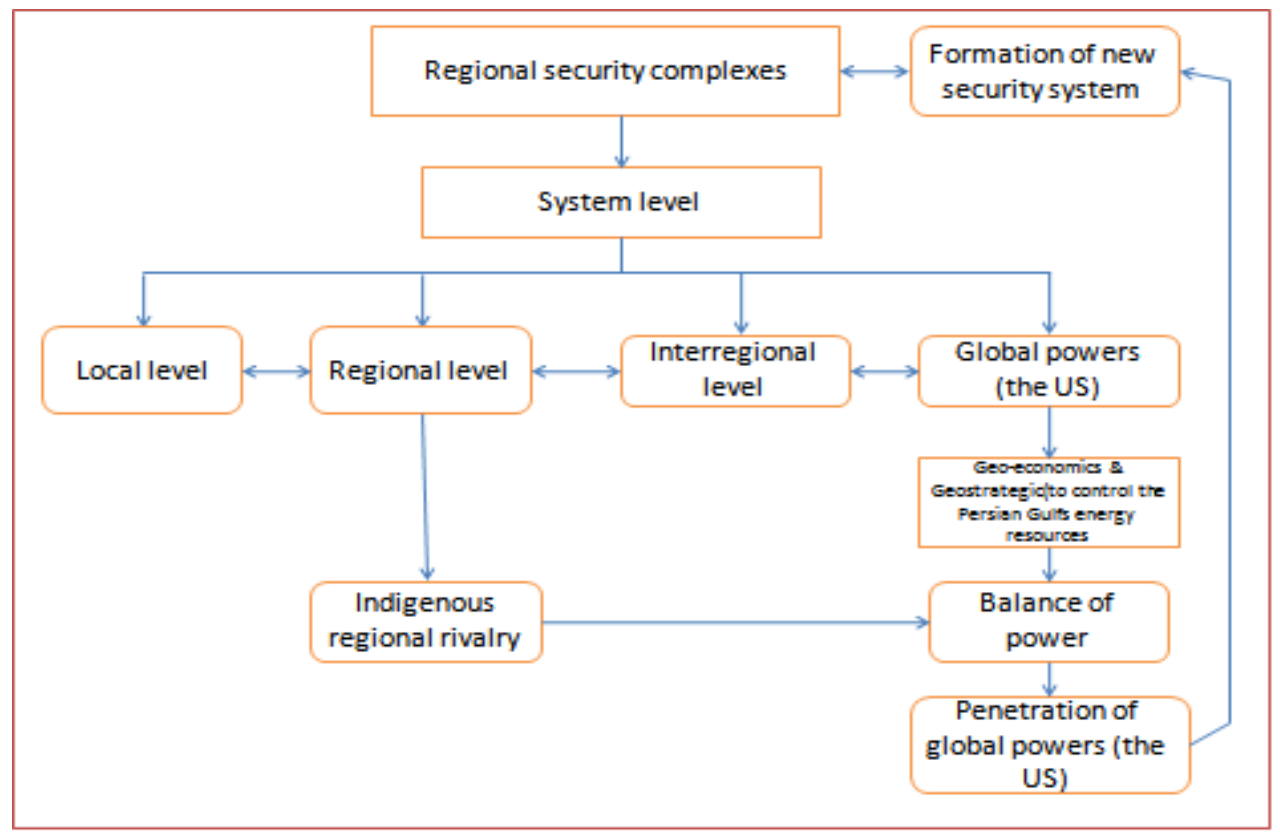




\section{Conclusions}

It is submitted that increase in Iran's importance and its enhanced regional role; emergence of a new Iraq with a different nature; changes in the nature of security challenges, have necessitated the formation of a new regional security system in the Persian Gulf based on political, cultural and security realities of the region. The Persian Gulf's traditional security system has been designed chiefly around the traditional threats and particularly based on the situations of the 1970s, 1980s and 1990s. Policies such as "Nixon's Doctrine", "balance of power", and "dual containment", for imposing imported security systems based only on the demands and interests of trans-regional players, have been the main components of such a security system. Today, according to new developments in international relations, such an arrangement that multiplies the causes of tension and mistrust between states in the region and external powers, is based on mutual misperception about roles, positions and objectives of other countries in the region is not in compliance with regional realities, and just as was demonstrated during the crises of recent years - the first and second Persian Gulf wars - it did not have the required efficacy. For the same reason, the current conditions and realities of the region without doubt demand a new regional security arrangement. The hypothesis of the present thesis is that the Islamic Republic of Iran has always sought to create conditions in which the security of the Persian Gulf region is assured through indigenous means, free from interference by outsiders.

\section{REFERENCES}

[1] Simbar, R., \& Ghorbani, A. (2011), Iran and the Persian Gulf Security. Iranian Review of Foreign Affairs, 2(5), 91-116.

[2] Asif, M., \& Khan, M. T. (2009), Possible Us-Iran Military Conflict and Its Implications upon Global Sustainable Development, Journal of Sustainable Development, 2(1), P3.

[3] Eia, D. O. E. (2006), DOE EIA, State Energy Profiles, US Department of Energy. Energy Information Administration (2006).

[4] Chubin, S. The Persian Gulf: Security, Politics, and Order In the Persian gulf.
[5] Pascual, C., \& Zambetakis, E. (2010), The Geopolitics of Energy from Security to Survival. Washington: The Brookings Institution.

[6] Maloney, S. (2010), Energy Security in the Persian Gulf; Opportunities and Challenges. In C. Pascual \& J. Elkind (Eds.), Energy Security;Economics, Politics, Strategies, and Implications (pp. 288). Washington, D.C.: Brookings institution press.

[7] Boer, K. d., Farrell, D., \& others, a. (2008). The coming oil windfall in the Gulf Retrieved. From Mc Kinsey Global Institute.

[8] Yazdan-fam, M. (2007-08). Persian Gulf Oil: US Challenges and Policies. The Iranian Journal of International Affairs, 10(1), 111-157.

[9] Florini, A. (2010). Global Governance and Energy. In C. Pascual \& J. Elkind (Eds.), Energy Security; Economics, Politics, Strategies, and Implications (pp. 288). Washington, D.C.: Brookings institution press.

[10] Strange, S. (1998). States and markets (2 Ed.). London: Continuum International Publishing Group.

[11] Saeed Taeb, \& Khalili, H. (2008). Security Building Priorities in Persian Gulf: An Approach to National Security Policy of Iran. The Iranian Journal of International Affairs 10(3), 27-71.

[12] Bilgin, P. (2004). Whose 'Middle East'? Geopolitical Inventions and Practices of Security. International Relations, $18(1), 25-41$

[13] Hurewitz, J. C. (1972). The Persian Gulf: British Withdrawal and Western Security. The Annals of the American Academy of Political and Social Science 40(1), 106-115.

[14] Bagat, G. (1999). Security in the Gulf: The View from Oman. Security Dialogue, 30(4), 445-458.

[15] Mraz, M. J. L. (1997). Dual Containment: US Policy in the Persian Gulf and a Recommendation for the Future [Electronic Version], 1-38.

[16] Kupchan, C. (2007). Toward a New Persian Gulf Security System: Lessons of the Asian Model. The Iranian Journal Of International Affairs, 11(2), 65-79.

[17] Buzan, B., \& Waever, O. (2003). Regions and Powers: The Structure of International Security. Cambridge University Press.

[18] Huntington, S. (1993). Huntington," The Clash of Civilizations?" Foreign Affairs, 72(3), 22-49. 